\title{
Girişimcilerin Gözünden Girişimciliği Etkileyen İçsel ve Dişsal Faktörler
}

DOI: 10.26466/opus.631493

\author{
Berat Ciçek* - Yusuf Emre Karakaş ** \\ * Dr. Öğr. Üyesi, Muş Alparslan Üniversitesi, İktisadi ve İdari Bilimler Fakültesi, Muş / Türkiye \\ E-Posta: b.cicek@alparslan.edu.tr \\ ORCID: 0000-0002-4584-5862 \\ ** Dr. Öğr. Üyesi, Malatya Turgut Özal Üni., İşletme ve Yönetim Bilimleri Fak., Malatya / Türkiye \\ E-Posta: y.emrekarakas@gmail.com \\ ORCID: $\underline{0000-0003-0123-7627}$
}

\section{Öz}

Bu çalışmada bireylerin girişimci olmasında rol oynayan içsel ve dışsal faktörlerin neler olduğu ve bu faktörlerden hangisinin girişimcilik kariyerini seçmede diğerlerine üstünlük kurduğunun ortaya konulması amaçlanmıştır. Bu amaç doğrultusunda nitel bir araştırma gerçekleştirilmiştir. Bu bağlamda Türkiye'nin çeşitti illerinde işyeri sahibi olan, 9'u erkek ve 7'si kadın olmak üzere toplam 16 girişimci ile derinlemesine görüşmeler yapılmıştır. Görüşmelerde önceden hazırlanmış ve 10 adet yarı yapılandırılmış sorudan oluşan görüşme formu uygulanmıştır. Elde edilen veriler tematik ă̆ analizi yöntemine göre NVivo paket programı aracıllğılyla analiz edilmiştir. Araştırmanın bulgularına göre bireyleri girişimciliğe iten unsurlar arasında içsel faktörler ve dişsal faktörler rol oynamaktadır. Fakat içsel faktörlerin daha etkili olduğu görülmüştür. Özellikle kişilik özelliklerinin girişimcilik kariyerini seçmede en önemli unsur olduğu tespit edilmiştir. Araştırma, içsel ve dışsal faktörleri bir arada irdelemesi ve girişimcilik kariyerini tercih etme potansiyeli olanlardan ziyade halihazırda girişimcilik yapan bireylere odaklanması yönüyle diğer çalışmalardan ayrılmaktadır. Ayrıca girişimcilerin görüşleri doğrultusunda sahip olunan ideallerin ve hayallerin bireyleri girişimciliğe iten birer faktör olmasının keşfedilmesi, çalışmanın literatüre yönelik özgün bir katkı sunmasını sağlamıştır.

Anahtar Kelimeler: Girişimcilik, Başarma İhtiyacı, Kontrol Odağı, Öz Yeterlilik, Sermayeye Erişim, İş ve Sektör Bilgisi, Sosyal Çevre, Girişimcilik Ĕ̆gitimi 


\title{
Internal and External Factors Affecting Entrepreneurship from the Eyes of Entrepreneurs
}

\begin{abstract}
In this study, it is aimed to reveal what the internal and external factors affecting entrepreneurship are and which of these factors have superiority over others in choosing the entrepreneurship career. For this purpose, a qualitative research was conducted. In this context, in-depth interviews were conducted with 16 entrepreneurs owning workplaces in various provinces of Turkey, 9 of whom are men and 7 of whom are women. During the interviews, a formerly prepared interview form consisting of 10 semi-structured questions was used. The data were analysed by NVivo package program according to thematic network analysis method. According to the findings of the study, internal factors and external factors play a role among the factors that push individuals to entrepreneurship. However, internal factors were found to be more effective. Especially personality traits were determined to be the most important factor in choosing the entrepreneurship career. The research differs from other studies in that it examines internal and external factors together and focuses on individuals who are already entrepreneurs rather than those who have the potential to choose an entrepreneurship career. In addition, the discovery of the ideals and dreams in the direction of the opinions of entrepreneurs as a factor prompting individuals to entrepreneurship has enabled the study to make an original contribution to the literature.
\end{abstract}

Keywords: Entrepreneurship, Need for Achievement, Locus of Control, Self-Efficacy, Access to Capital, Business and Sector Knowledge, Social Network, Entrepreneurship Education 


\section{Giriş}

Girişimcilik büyük bir istihdam, ekonomik büyüme ve teknolojik gelişme kaynağıdır (Kuratko, 2007). Dünya çapında yapılan araştırmalara göre girişimcilik oranlarında artışa sahip bölgelerin işsizlik seviyeleri hızla düşmektedir (Audretsch vd., 2002). Buna rağmen girişimciliğe olan rağbet oldukça azdır (Liñán vd., 2011). Örneğin OECD ülkelerinde girişimcilik faaliyetlerine yetişkin nüfusunun \%10'undan dahi az bir oranda bireyin başladığı rapor edilmiştir (Athiyaman vd., 2007). Bu nedenle, ekonomik kalkınmayı ve istihdamın oluşturulmasını teşvik etmek için girişimciliği teşvik etmenin önemi hakkında literatürde geniş çaplı bir sözbirliği vardır (Mitra, 2008). Çünkü ekonomik büyüme, yüksek istihdam, güçlü iş yaratma ve olumlu sosyal gelişim sağlamada öncü bir faktör olarak dikkat çeken girişimcilik, son yıllarda her zamanki öneminden daha da önemli bir hale gelmiştir (Acs vd., 2005).

Taşıdığı önemli misyonları ve toplumlara sağladığı faydaları yönüyle girişimcilik önemli bir kavram olarak ele alınmakta bununla birlikte literatürde sürekli bir araştırma ve tartışma konusu olarak karşımıza çıkmaktadır. Girişimcilik konusundaki önemli tartışmalardan biri de bireyleri girişimciliğe iten faktörler olmuştur ve bu faktörler üzerinde kimse kesin bir sonuca ulaşamamıştır (Busenitz vd., 2003). Bu bağlamda özellikle bilişsel yaklaşımlar ön plana çıkmaya başlamıştır (Baron, 2004; Gatewood vd., 1995). Bu yaklaşıma göre girişimciliğin zekanın işleyişiyle ilgili bir eğilim olduğu savunulmuştur (Izquierdo ve Buelens, 2011; Krueger Jr vd., 2000). Buna karşın kişilik özellikleri ve demografik özelliklerin girişimcilik üzerinde etkiye sahip olduğu görüşü hala oldukça yaygin bir görüştür (Mazzarol vd., 1999; Rauch ve Frese, 2007). Burada ortaya iki durum çıkmaktadır. Bazı araştırmacılar (Thompson, 1999) girişimciliğin bireyin içinden gelen ve böylelikle insanları girişimcilik yapmaya iten bir davranış olduğunu savunurken; diğer araştırmacılar $(\mathrm{Ku}-$ ratko, 2005; Peterman ve Kennedy, 2003) girişimciliğin öğrenilebilir bir olgu olduğunun altını çizmişlerdir. Bu nedenlerle bireylerin girişimcilik kariyerini tercih etme sebeplerinin netleştirilmeye ihtiyacı vardır.

Literatürde konuyla ilgili birçok tartş̧ma olsa da girişimciliği etkileyen faktörlerle ilgili hala büyük bir boşluğun olduğunu da kabul etmek gerekmektedir. Bu bağlamda bu çalışmanın temel hedefi girişimcilerin ağzından kendilerini girişimciliğe iten nedenlerin ortaya konulmasıdır. Bu konuda yapılan önceki çalışmalar (Boyd ve Vozikis, 1994; Crant, 1996; Dakhli ve De 
Clercq, 2004; Krueger Jr vd., 2000; Robinson ve Haynes, 1991; Wilson vd., 2007) girişimciliği etkileyen spesifik bir faktörü alıp inceleme yoluna giderken bu çalışmada içsel ve dışsal faktörler bir arada irdelenmeye çalışılmıştır. Böylelikle bireyleri girişimcilik kariyerine iten öncüllerin ortaya konulması çalışmanın temel amacıdır. Daha önce bu yönde yapılan keşifsel araştırmalar (Douglas ve Shepherd, 2002; Robinson ve Haynes, 1991; Sesen, 2013) özellikle girişimcilik kariyerini tercih etmeyi düşünen bireylere yoğunlaşmışlardır. $\mathrm{Bu}$ çalışmada halihazırda girişimci olan bireylere uygulanması da çalışmanın başka bir özgün yönüdür.

Çalışma, literatür taramasını içeren ilk kısmın yanı sıra yarı yapılandırılmış sorular ile mülakat tekniğine dayalı görüşmelerle elde edilen verilerin analizine yönelik bir araştırma kısmına da sahiptir. Böylelikle girişimcilerin gözünden kendilerini bu kariyere iten öncüller birincil kaynaklardan incelenmiştir. Bu bağlamda çalışmanın, girişimciliği belirleyen faktörlerden hangisinin üstün olduğunu ortaya koyması beklenmektedir.

\section{Girişimcilik ve Girişimciliği Etkileyen Faktörler}

Girişimcilik ekonomi, psikoloji, sosyoloji ve stratejik yönetim gibi alanları kapsayan köklere sahip çok boyutlu bir disiplindir (Mitchell vd., 2002) çünkü girişimciler birey ve toplum için değer yaratabilir, ekonomik firsatlara cevap verebilir, hatta getirdiği yeniliklerle ekonomik sistem içerisinde sosyolojik değişikliklere neden olan bir süreci başlatabilir (Muzyka vd., 1995). Çiçek (2018) girişimcileri "üretim faktörlerini bir araya getirip bir ürün veya hizmet sunmayı amaçlayan ve tüm bu faaliyetler sonucunda olası riskleri üstlenmek suretiyle bir organizasyon oluşturan bireyler" olarak tanımlamıştır. Başka bir tanımda Shane (2003) girişimciyi "yenilikleri ekonomik ürünlere dönüştürmek için inovasyonu, finansı ve iş zekasını üstlenen kişiler" olarak tanımlamaktadır.

Yukarıdaki tanımlardan da anlaşılacağı üzere girişimciler çok yönlü bir fonksiyona ve meziyete sahiptir. Araştırmacılar (Blawatt, 1995; Burns, 2016; Cunningham ve Lischeron, 1991; Douglas ve Shepherd, 2002; Haynie vd., 2010; McGrath vd., 2000; Nieman, 2006) girişimcilerin başlıca özelliklerini ve yerine getirdikleri fonksiyonları: "yenilikçi, iyimser, kararlı, belirsizliğe karşı hoşgörülü, lider vasıflarına sahip, sonuç odaklı, risk alabilen, esnek, 
öğrenebilen, bağımsızlık hissini seven, becerikli, başarı ihtiyacı olan, çevresine duyarlı, azimli, uzun dönemli kendini adayabilen, performans ölçütü olarak parayı gören, fırsatçı, vizyon sahibi, planlama/örgütleme becerisine sahip, içsel kontrole sahip ve hırslı" olarak sıralamışlardır.

McClelland (1962) girişimciliğe ait özelliklerin doğuştan geldiğini savunsa da bu duruma karşıt görüşler zaman içerisinde daha kabul görür hale gelmiştir. Böylelikle girişimciliği etkileyen unsurlar olarak eğitim (Katz, 2003; Kuratko, 2005; McMullan ve Gillin, 2001; Oosterbeek vd., 2010), kişilik özellikleri (Baum vd., 2014; Brandstätter, 2011; Rauch ve Frese, 2007) ve çevresel koşullar (Acs ve Audretsch, 2003; Schmitt-Rodermund, 2004) ön plana çıkmıştır.

\section{Girişimciliği Etkileyen İçsel Faktörler}

Girişimciliği etkileyen kişilik özellikleri yani içsel faktörler; başarma ihtiyacı (Carraher vd., 2010; Hansemark, 1998; McClelland, 1965; Perry vd., 1986), kontrol odağı (Brockhaus, 1975; Mueller ve Thomas, 2001) ve öz yeterlilik (Bandura, 1977; Barbosa vd., 2007; Boyd ve Vozikis, 1994; Wilson vd., 2007) olarak kabul görmektedir. Bu faktörler literatürde kabul gören başlıca faktörlerdir ve sırasıyla aşağıda açıklanmıştır.

\section{Başarma İhtiyacı}

McClelland (1965) girişimcilik için önemli motivasyonlardan biri olarak başarma ihtiyacını işaret etmiştir. Başarma ihtiyacını ise "herhangi birinden daha iyi veya daha hızlı bir şeyler yapabilmek veya bireyin daha önceki yaptıklarından daha iyi bir şeyler yapma isteği" olarak tanımlamıştır. Hansemark (1998) bu ihtiyacın, bireylerin başarılı olmasının temel belirleyicilerinden biri olduğunu iddia etmiştir. Bu noktadan bakıldığında başarma ihtiyacı için "mükemmelliğe ulaşmak için bir planlama ve çabalama süreci" tanımlaması yapmak mümkündür.

Başarma ihtiyacı girişimcilerin sahip olması gereken bir özellik olarak literatürde sıkça tartışılsa da bazı çalışmalar bu özelliğin sonradan öğrenilebileceğini savunmuştur (McClelland, 1987). Sonuçta öğrenilmiş de olsa veya doğuştan gelen bir özellik de olsa bir kişilik özelliği olarak kabul gör- 
düğünden içsel bir faktör olarak ele alınmaktadır. Girişimcilik eğilimiyle ilgili yapılan çalışmalarca (Carraher vd., 2010; Collins vd., 2004; Lee, 1996; Wu vd., 2007) başarma ihtiyacının yüksek olduğu bireylerde girişimcilik eğiliminin de arttığ bunu tam tersi olduğu durumlarda ise girişimcilik eğiliminin azaldığı ampirik olarak ortaya konulmuştur. Başarma ihtiyacına sahip bireylerde girişimcilik eğiliminin artabileceği gibi halihazırda girişimcilik faaliyetleri içerisinde olanların başarma ihtiyaçlarının artırılması gerekmektedir. Böylece mevcut girişimciler daha üstün başarılar peşinden koşarak daha etkili girişimciler olabileceklerdir ( $\mathrm{Wu}$ vd., 2007). Buradan hareketle bu araştırmaya katılan katılımcıların başarma ihtiyaçları ve bu ihtiyacın onların girişimcilik seyrine olan etkisi irdelenmeye çalışılmıştır.

\section{Kontrol Odağı}

Bir girişimcinin, girişiminin başarısını veya başarısızlığını etkileme yeteneğine sahip olduğuna inanma eğiliminde olduğu söylenebilir (Brockhaus, 1975). Bu eğilimi açıklayan teori ise kontrol odağıdır. Kontrol odağı motivasyonel bir eğilim gibi görülse de sadece insanları motive eden bir olgudan çok daha fazlasıdır (Zigarmi vd., 2018). Çünkü, kontrol odağı bireylerin elde ettikleri sonuçları kimin veya neyin kontrol ettiğine inandıkları ile ilgilidir (Asante ve Affum-Osei, 2019). İlk kez Rotter (1966) tarafından kullanılan kavram, bir kişinin elde ettiği ödülleri kendi davranış ve çabalarına bağlı görmesini sağlayan iç kontrol odağ1 ve bir kişinin elde ettiği ödülleri kendi benliği dışındaki güçlere bağlayan yani kendi eylemlerinden bağımsız olarak gerçekleştiğine inandığı dış kontrol odağı olmak üzere ikiye ayrılmaktadır.

Kavram girişimcilik açısından ele alındığında, iş yaşantısında elde edilen sonuçların kişinin kendi davranışlarına bağlı olduğu görüşü daha fazla ağırlık kazanmaktadır (Zigarmi vd., 2018). Konuyla ilgili yapılan araştırmalara (Charoensukmongkol, 2019; Embi vd., 2019; Lüthje ve Franke, 2003; Shane, 2003) göre iç kontrol odağı ile girişimcilik niyeti arasında pozitif yönlü bir ilişki olduğu belirlenmiştir. Ayrıca kontrol odağının rekabet üstünlüğü kurma üzerinde de olumlu bir etkiye sahip olduğu belirlenmiştir (Wijbenga ve van Witteloostuijn, 2007). Bu bilgiler 1şığında kontrol odağ1nın girişimciliği etkileyen önemli bir içsel faktör olduğu görülmüştür. $\mathrm{Bu}$ nedenle girişimciliği etkileyen bir unsur olarak kontrol odağının, özellikle 
iç kontrol odağının girişimciler açısından önemi bu araştırmada ortaya konulmaya çalışılmıştır.

\section{Öz Yeterlilik}

Öz yeterlilik terimi, Bandura (1977)'nın sosyal öğrenme teorisinden türetilmiştir ve bir kişinin belirli bir görevi yerine getirme kabiliyetine olan inancını ifade etmektedir. Zaman içerisinde girişimcilik niyeti üzerindeki önemli etkisiyle birlikte girişimcilik alanında yoğun bir biçimde irdelenmeye başlamıştır. Hatta girişimcilik öz yeterliliği şeklinde bir kavram ortaya atılmaya başlanmıştır (Sesen, 2013). Girişimcilik öz yeterliliği genellikle; "bir insanın bir girişimi başlatmak ve yürütmek için özel görevleri başarıyla yerine getirme kabiliyetine güvenmesi" olarak tanımlanır (Chen vd., 1998). Öz yeterliliği düşük olması bireylerin, belirli durumlardan kaçınmasına neden olabilir ve bu kaçınma davranışı, bireyin korkularla yüzleşmekten veya yetkinliklerden kaçınmasını doğurur (Bandura, 1977). Buna karşılık yüksek öz yeterlilik engeller karşısında kararlı bir davranış sergilenmesine, yüksek çaba ve azim gösterilmesini sağlar (Thomas ve Velthouse, 1990).

Girişimcilik alanında öz yeterliliği ele alan ampirik çalışmaların sayısı da bir hayli artmaktadır (Chen vd., 1998; McGee vd., 2009; Wilson vd., 2007). Bu çalışmaların çoğu öz yeterliliğin bireyin yeni bir girişim başlatma niyetini nasıl etkilediği üzerine odaklanmıştır (McGee ve Peterson, 2019). Bu çalışmalara göre öz yeterlilik girişimcilerin risk alma, fırsat tanıma ve ısrar etme gibi davranışlarına bağlıdır (Bradley ve Roberts, 2004). Ayrıca öz yeterlik, girişimcilik niyetine ve eylemine de katkıda bulunur (Chowdhury vd., 2018). Çoğu zaman kontrol odağıyla bir arada kullanılan öz yeterlilik (Ajzen, 2002; Judge vd., 2002; Nykänen vd., 2019) bireyleri girişimcilik kariyerine iten önemli bir içsel faktör olarak karşımıza çıkmaktadır. Bu nedenle çalışmada öz yeterliliğin girişimcilik kariyerini tercih etmedeki etkisinin ortaya konulması amaçlanmıştır.

\section{Girişimciliği Etkileyen Dışsal Faktörler}

Girişimciliği etkileyen dişsal faktörler başlıca; sermayeye erişim (Bates, 1985; Blanchflower ve Oswald, 1998; Giné, 2011), iş ve sektöre ilişkin bilgi 
(Clercq ve Arenius, 2006; Minniti ve Bygrave, 1999), sosyal ağlar ve sosyal çevre (Davidsson ve Honig, 2003; Greve ve Salaff, 2003) ve girişimcilik eğitimleri (Kuratko, 2005; Peterman ve Kennedy, 2003; Wilson vd., 2007) olarak karşımıza çıkmaktadır.

\section{Sermayeye Erişim}

Sermayeye erişim yalnızca gelişmekte olan ekonomilerde değil, dünyanın her yerinde girişimciliğe başlamanın önündeki en önemli engellerden biridir (Kristiansen ve Indarti, 2004). Sermayenin küçük işletmelerin yenilik yapmasını, büyümesini ve iş yaratmasını sağlayan en önemli bileşenlerden biri olduğu düşünüldüğünde girişimciliğe başlarken ne denli önemli olduğu daha iyi anlaşılabilecektir (Coleman, 2000). Yapılan birtakım çalışmalara (Coleman, 2000; Steel, 1994) göre birçok insanın sermaye bulamadığı için girişimcilik kariyerinden vazgeçtiği belirlenmiştir. Sermayeye erişim girişimciliğin önünde önemli bir engel teşkil ettiği için dünyanın en kapitalist ülkelerinde dahi girişimcilere ciddi oranlarda devlet desteği sunulmaktadır. Böylelikle özellikle girişimciliğe başlanılan ilk yıllarda girişimcileri olabildiğince finanse etmek suretiyle ekonomiye katılımlarının sağlanması amaçlanmaktadır.

\section{İş ve Sektöre İlişkin Bilgi}

İş ve sektöre ilişkin bilgilere sahip olunması, yeni bir girişim başlatmak ve sürekli bir büyüme sağlamak için oldukça önemlidir (Kristiansen ve Indarti, 2004). Özellikle rekabet avantajı sağlayabilmek için bir işe başlamadan önce piyasa hakkındaki bilgilere çok ihtiyaç duyulmaktadır. Girişimcilik kararı bilişsel süreçlerden geçilerek alındığı için pazar fırsatları ancak doğru bilgiyle yakalanabilmektedir (Sesen, 2013). Yapılan araştırmalar bireylerin mevcut bilgi ve yeteneklerinin davranışları için önemli bir faktör olabileceğini göstermiştir. Başka bir deyişle literatür, ekonomik faaliyetleri açıklamada insan sermayesinin önemini vurgulamıştır (Becker vd., 1990; J. S. Coleman, 1988). İnsan sermayesi ise işe başlama ve faaliyete geçirme faaliyetleri için geçerli olan bilgiler ile ilgili bir kavramdır (Clercq ve Arenius, 2006).

Girişimcilik faaliyeti hakkındaki bilgiye dayalı bakış açısı, yalnızca birisinin girişimcilik konusunda sahip olduğu bilgi tabanının oynadığı bir rolü 
değil, aynı zamanda bir kişinin dış bilgiye ulaşabilmesi anlamına da gelmektedir (Putnam vd., 1994). Başka bir ifade ile sektörle ilgili bilgiye sahip kimselerle bir arada olmak da girişimciler için oldukça önemli bir kazanımdır (Davidsson ve Honig, 2003) çünkü insanlar bilgiyi birleştirme ve özümseme yetenekleri ve karar alternatiflerinin sonuçlarını belirleme konusunda sınırlı bir kapasiteye sahiptir. Bu nedenle karar almak için gerekli bilgiyi elde etmek adına sıklıkla dış temaslara güvenmek zorundadırlar (Peters ve Brush, 1996). Özetle girişimcilik yapabilmek için iş, sektör, pazar vb. ile ilgili sadece salt verilerden ziyade bunları doğru bir şekilde kullanabilme bilgi ve becerisine de sahip olunmalıdır.

\section{Sosyal Ă̆ ve Çevre}

Sosyal ağ veya sosyal çevreye odaklanan araştırmalar, girişimciler ve bir işletme kurulmasında önemli olan kaynakları sağlayan diğer kişiler arasındaki ilişkilere dikkat çekmektedir (Larson, 1991). Bunun temel sebebi, yakın zamandaki çalışmaların girişimcileri özerk ve rasyonel karar vericiler olarak görmekten ziyade, sosyal çevrenin ön plana çıkarmasıdır (Hoang ve Antoncic, 2003). En geniş anlamıyla sosyal çevre, bir dizi oyuncu (bireyler veya kuruluşlar) ve bu oyuncular arasındaki bağlantılarla tanımlanmaktadır (Brass, 1992). Girişimcilerin test etmek için fikirleri ve işi yürütmek için bazı bilgi ve yetkinlikleri vardır. Ancak ayn zamanda mal veya hizmetlerini üretmek ve sunmak için tamamlayıcı kaynaklara ihtiyaçları vardır (Teece, 1993). Girişimciler, kendi aralarında etkileşime giren insan ve kuruluşlarla bağlantılıdır ve bu bağlantılar yeni bir şirketi sürdüren kaynakların kullanılabilirliğini genişletebiliyor. Başka bir deyişle sahip oldukları sosyal ağları aracılığıyla dağıtım kanallarına destek, bilgi ve erişim sağlayabiliyorlar (Hansen, 1995). Bu noktalardan bakıldığında sosyal çevrenin girişimciler ve girişimci adayları için oldukça önemli bir unsur olduğunu görebiliyoruz.

Sosyal ağlar denilince akla her ne kadar ilk olarak sosyal çevre gelse de formel ve informel ağların yeni girişim oluşturmayı desteklemek ve teşvik etmek için kritik öneme sahip olduğunu belirtmek gerekir (Neck vd., 2004). Hatta girişimcilerin sahip olduğu bu ağları tarif etmek için son yıllarda "girişimcilik ekosistemi" adında bir olgu ortaya çımaya başlamıştır (Neumeyer vd., 2019). Girişimcilik ekosistemleri, girişimcilik girişimlerini ve eylem- 
lerini gerçekleştiren ve destekleyen belirli bir coğrafi alandaki birbiriyle ilişkili bireylerin, kurumların, kuruluşların ve düzenleyici varlıkların toplanması olarak tanımlanmaktadır (Isenberg, 2010). Kuşkusuz bu ekosistemler girişimciler açısından oldukça önemlidir. Çünkü girişimciler sosyal ağlarından finansal yardım, endüstri bilgisi, sosyal destek ve güven gibi girişimlerini geliştirip büyütmede hayati bir öneme sahip unsurlara sahip olabilmektedir (Cope vd., 2007).

\section{Girişimcilik Eğitimi}

Yıllarca girişimciliği etkileyen temel unsurların; aile, rol modeller, motivasyon, kültür, kişilik özellikleri vb. olduğuna inanılmıştır. Ancak son yıllarda, eğitiminde girişimcilik eğilimi açısından önemli bir unsur olduğundan sıkça söz edilmeye başlanmıştır (Çiçek, 2016). Hatta bu tartışmalar klasik anlamda girişimcilik eğitiminin aşılması gerektiği ve inovatif eğitim yöntemleriyle geleceğin girişimcilerinin hazırlanması gerektiğini vurgulamaya başlamıştır (Akhmetshin vd., 2019). Girişimcilik eğitimi konusunda çeşitli tanımlamalar yapılsa da temelde girişimcilik eğitimi iki anlama gelmektedir. Bunlardan ilki; girişimcilik için çok önemli olan kişisel niteliklerin, tutumların ve becerilerin geliştirilmesini kapsamaktadır. İkincisi ise girişimcilik serüveni oluşturmak için verilen özel bir kurs şeklinde düşünülebilir (Fayolle ve Gailly, 2008). Bu eğitimin üniversiteler aracılığıyla (Galloway ve Brown, 2002; Gürol ve Atsan, 2006; Robinson ve Haynes, 1991) verilebileceği gibi, kamu destekli (Çiçek ve Karakaş, 2015; O'Connor, 2013) veya özel sektör (Hynes, 1996; Ladzani ve Van Vuuren, 2002) aracılığıyla verilmesi de mümkündür. Yapılan araştırmalar (Liñán vd., 2011; Yu Cheng vd., 2009) girişimcilik eğilimini belirleyen önemli bir unsur olarak girişimcilik eğitimlerini ortaya koymaktadir.

\section{Yöntem}

Girişimcilik alanındaki çalışmaların çoğunlukla nicel olmasından ötürü konunun olgu bilimi deseni içerisinde incelenmesinin ilgili literatürü derinleştireceği varsayımından hareket edilmiştir. Strauss ve Corbin (1998)'e göre nitel araştırma bireylerin hayat tarzlarını, hikayelerini, davranışlarını, örgütsel yapıları ve toplumsa değişmeyi anlamaya yönelik etkin bilgi üretme 
süreçlerinden biridir. Bu paradigma çerçevesinde derinlemesine görüşme yönteminin uygun olacağına karar verilmiştir. Bu bağlamda Eylül 2018 Temmuz 2019 zaman aralığında biri pilot uygulama olmak üzere toplamda 16 girişimci ile mülakatlar gerçekleştirilmiştir.

Nitel araştırmalarda örneklem büyüklüğüyle ilgili çeşitli yaklaşımlar mevcuttur. Örneğin; Guest, Bunce ve Johnson (2006) 7 ila 12 arasında görüşmenin yeterli olduğunu savunurken Namey vd. (2016) 8 ila 16 arasında görüşmenin ideal olacağını belirtmiştir. Bu konuda nicel yaklaşımlardaki gibi bir netlik olmadığından bu çalışmada Glaser ve Strauss'un (2017) “doyum noktası" yaklaşımı benimsenmiştir. Bu yaklaşıma göre, katılımcıların cevapları birbirleriyle benzerlik göstermeye başladığı taktirde örneklem büyüklügünün yeterli olduğuna kanaat getirilmektedir. Bu çalışmada 16 katılımcının cevaplarının, girişimciliğin içsel ve dışsal faktörlerini açıklamaya yeterli olduğu görülmüştür. Bu nedenle örneklem büyüklüğünün yeterli olduğuna kanaat getirilmiştir.

Katılımcılar amaçlı örnekleme yaklaşımına göre seçilmiştir. Bu yaklaşımın seçilmesinin temel sebebi katılımcıların bilgi açısından zengin oldukları varsayımıdır (Easterby-Smith vd., 2012). Amaçlı örnekleme türlerinden ise tipik durum örneklemesi tercih edilmiştir. Katılımcıların tümü girişimci olduğu için aynı kümeye dahil olacakları varsayımıla bu örnekleme yöntemi tercih edilmiştir. Katılımcılarla ilgili bilgiler Tablo 1'de verilmiştir.

\section{Tablo 1. Katılımcı Bilgileri}

\begin{tabular}{lllllr}
\hline Kod & Sektör & Cinsiyet & Yaş & Eğitim & Şehir \\
\hline K1 & Eğitim & Kadın & 36 & Lisans & Malatya \\
K2 & Şarküteri malzemeleri satışı & Kadın & 29 & ÖnLisans & Elazı̆̆ \\
K3 & Uzay ve havacılık alanında belirli parçaların & Kadın & 42 & Lisans & Ankara \\
& imalatı & & & & \\
K4 & Mimarlık projeleri & Kadın & 32 & Lisans & Antalya \\
K5 & Kuaför ve güzellik merkezi & Kadın & 25 & Lise & Antalya \\
K6 & Kobi Danışmanlığı & Kadın & 45 & Lisans & Malatya \\
K7 & Hazır giyim tekstil imalatı & Kadın & 60 & Lise & Osmaniye \\
E1 & İlaç sektörü & Erkek & 26 & Lisans & Antalya \\
E2 & Dondurulmuş gıda ürünleri satışı & Erkek & 28 & Lisans & Antalya \\
E3 & Süs eşyaları, mobilya aksesuar vb. imalatı & Erkek & 39 & Lise & Elazı̆̆ \\
E4 & Süt ürünlerin imalatı & Erkek & 40 & Lise & Antalya \\
E5 & E-Ticaret & Erkek & 32 & Lisans & Antalya \\
E6 & Kozmetik ürünlerin imalatı & Erkek & 33 & Lise & Antalya \\
E7 & İlaç sektörü & Erkek & 25 & Lisans & Antalya \\
E8 & Elektrik malzemeleri toptan satış & Erkek & 44 & ÖnLisans & Antalya \\
E9 & Fuar Organizasyonu & Erkek & 44 & Lisans & İstanbul \\
\hline
\end{tabular}


Araştırmaya başlanmadan önce farklı illerde ikamet eden ve konuya katkı sunması beklenen girişimcilerden bir havuz oluşturulmuştur. Daha sonra havuzdaki tüm girişimcilere konuyu açıklayan bir e-posta gönderilerek görüşme talebi iletilmiştir. Görüşmeyi kabul eden girişimcilerden randevu talep edilerek 14 kişi ile yüz yüze, 2 kişi ile ise telefonda mülakatlar gerçekleştirilmiştir. Katılımcılara 10 adet yarı yapılandırılmış soru yöneltilmiştir (sorular çalışmanın ekinde verilmiştir). Görüşmeler 28 ila 55 dakika arasında sürmüştür. Katılımcılardan izin alınarak görüşmeler kaydedilmiştir. Daha sonra transkripsiyonu yapılmıştır.

$\mathrm{Bu}$ çalışmada araştırmanın geçerliliğine ve güvenilirliğine yönelik ciddi bir hassasiyet gösterilmiştir. Geçerlilik ve güvenilirliği artırmak adına öncelikle amaçlı örnekleme yöntemi tercih edilmiştir. Creswell (2009) ve Shenton (2004) nitel araştırmalarda dış geçerlilik ve güvenilirlik açısından en güçlü örnekleme yöntemlerinden birinin amaçlı örnekleme yöntemi olduğunun altını çizmişlerdir. Bu bağlamda araştırmanın örneklemi farklı sektörlerde faaliyette bulunan girişimcilerden oluşmuştur. Bu durumda örneklem oldukça homojen bir yapıdadır ve bu homojenlik dış geçerlilik ve güvenilirlik açısından oldukça önemlidir (West, 2001). Araştırmada geçerlilik ve güvenilirliği artırmak adına izlenen başlıca diğer stratejiler ise dış güvenilirliği sağlamak için, çalışmanın başka bir zaman diliminde farklı araştırmacılar tarafından tekrarlanması ihtimaline karşı, veri toplama ve analizi ile ilgili sürecin mümkün olduğunca ayrıntılı tanımlanmasına özen gösterilmiştir (Yıldırım ve Şimşek, 2005). Ayrıca araştırmanın içerik geçerliliğini sağlamak amacıyla Eryılmaz (2011) tarafından önerilen adımlar atılmıştır. Buna göre görüşme soruları hazırlanırken konunun uzmanlarıyla görüşülmüştür ve hazırlanan soruların araştırmanın amacına uygunluğu uzmanlarca kontrol edilmiştir. Tüm bu adımlarla birlikte araştırmada geçerlilik ve güvenilirlik açısından herhangi bir sorun olmadığı düşünülmektedir.

\section{Analizler}

Toplanan verileri sistematik bir şekilde analiz etmek için Attride-Stirling (2001) tarafından önerilen tematik ağ analizi yöntemi uygulanmıştır. Ortaya çıkan bulguların anlaşılmasını kolaylaştırmak için ve verileri anlamlı ve yönetilebilir bölümlere ayırmak için metinsel verilere ön kodlar uygulanmıştır. 
Kodlar tematik ağ analizinde önerildiği gibi temaları oluşturacak şekilde belirlenmiştir. Bu işlem NVivo 11 programı aracllı̆̆ıyla bilgisayar ortamında yapılmıştır. Bu bağlamda üç adet global tema ortaya çıkmıştır. Ayrıca temaları açıklamayı kolaylaştıracak düzenleyici temalar da oluşturulmuştur. Oluşan global temalar ve düzenleyici temalar Tablo 2'de verilmiştir.

\section{Tablo 2. Araştırmanın Temaları}

\begin{tabular}{|c|c|}
\hline Global Tema 1: İçsel Faktörler & $\begin{array}{l}\text { Düzenleyici Tema 1: Kişilik Özellikleri } \\
\text { Kod 1: Girişimci kişilik özelliği } \\
\text { Kod 2: Bireyin kişilik özellikleri } \\
\text { Kod 3: Kişilik özelliklerinin girişimcilik kariyerine etkisi } \\
\text { Düzenleyici Tema 2: Başarma İhtiyacı } \\
\text { Kod 1: Başarma ihtiyacı durumu } \\
\text { Düzenleyici Tema 3: Öz Yeterlilik } \\
\text { Kod 1: Yetersiz görülen durumlar } \\
\text { Düzenleyici Tema 4: Kontrol Odağ1 } \\
\text { Kod 1: Kadercilik } \\
\text { Kod 2: İç kontrol odağ1 }\end{array}$ \\
\hline Global Tema 2: Dişsal Faktörler & $\begin{array}{l}\text { Düzenleyici Tema 1: Sermayeye Ulaşım } \\
\text { Kod 1: Öz finansman yeterliliği } \\
\text { Kod 2: Finansmanı kaynakları } \\
\text { Kod 3: Finansman bulma sorunu } \\
\text { Düzenleyici Tema 2: Sektör Bilgisi } \\
\text { Kod 1: Sektöre ilişkin bilgi erişiminde yaşanan zorluklar } \\
\text { Kod 2: Pazar, çevre, prosedür vb. bilgilere erişmede yaşanan so- } \\
\text { runlar } \\
\text { Kod 3: En temel bilgi kaynağı } \\
\text { Kod 4: Bilgi akışı } \\
\text { Düzenleyici Tema 3: Sosyal Çevre } \\
\text { Kod 1: Aile çevresi } \\
\text { Kod 2: Arkadaş çevresi } \\
\text { Düzenleyici Tema 4: Girişimcilik eğitimi } \\
\text { Kod 1: Üniversite eğitimi } \\
\text { Kod 2: KOSGEB girişimcilik eğitimi }\end{array}$ \\
\hline Global Tema 3: Güçlü Faktör & $\begin{array}{l}\text { Düzenleyici Tema 1: Girişimciliği Seçmedeki En Güçlü Faktör } \\
\text { Kod 1: İçsel Faktörler } \\
\text { Kod 2: Dışsal Faktörler }\end{array}$ \\
\hline
\end{tabular}

Tablodan da anlaşılacağı üzere girişimciliği etkileyen faktörler üç global temaya ayrılmıştır. Bunlar, girişimciliği etkileyen içsel faktörler, dışsal faktörler ve girişimciliği etkileyen en güçlü faktör olarak sınıflandırılmıştır. Bu temaları daha derinden incelemek için düzenleyici temalar ve düzenleyici temaları daha detaylı irdelemek için kodlar oluşturulmuştur. Bu bağlamda görüşmeler ele alınarak deşifre edilmiştir. 


\section{Bulgular}

Global Tema 1- İçsel Faktörler: Öncelikle bireyleri girişimcilik kariyerine iten içsel faktörlerin ortaya konulması hedeflenmiştir. Bu doğrultuda oluşan düzenleyici temalar; kişilik özellikleri, başarma ihtiyacı, öz yeterlilik ve kontrol odağı olmuştur. Bu bağlamda bireyleri girişimciliğe iten ve bireyin içinden gelen temel motivasyonlar bu global tema altında toplanmıştır. Dört düzenleyici temadan oluşan bu kısmı irdelemek için katılımcılara yöneltilen başlıca sorulara, düzenleyici temalara göre katılımcıların verdikleri cevaplar aşağıdaki gibidir.

Düzenleyici Tema 1-Kişilik Özellikleri: Kişilik kuramları temelde, insanların taşıdıkları kişilik özelliklerinin onların davranışlarını, tercihlerini, hayat tarzlarını, olaylar karşısındaki tutumlarını etkileyebileceği üzerinde durmaktadır (Çiçek ve Aknar, 2019). Buradan da hareketle kişilik özelliklerinin bireyi girişimcilik kariyerini seçmeye iten bir unsur olarak görmemek mümkün değildir. Bu nedenle bireyi girişimcilik kariyerine iten içsel faktörlerin başında kişilik özellikleri incelenmiştir. Burada konu üç temel kod çerçevesinde irdelenmiştir. Buna göre katılımcılara öncelikle girişimci kişiliğin nasıl olması gerektiği sorulmuştur daha sonra kendi kişilik özelliklerinin nasıl olduğu ve son olarak taşıdığı kişilik özelliklerinin bireyi girişimciliğe itip itmediği sorulmuştur. Bu konuda erkek katılımcı $4^{\prime}$ ün verdiği cevap aşağıdaki gibidir.

"Bir girişimci öncelikle kendine öz güveni olan, risk almayı seven ve bulunduğu ortamda firsatlarn gözlemleyebilecek bir yapıya sahip olmalıdır. Ben de risk almayı seven ve kendine özgüveni yüksek birisiyim... Başkasının yanında sinırl ve belirli bir kazancım olacă̆ına burada yaptı̆̆ım girişim sonunda belki de yıl sonunda kazandığım parayı sadece iki üç ay içerisinde kazanma ihtimalimin olması sebebiyle böyle bir riske girilir düşüncesiyle bu işe atıldım ve iyi ki de yapmışım (Erkek, 39, Lise Mezunu, Antalya)."

Bu düzenleyici temada en sık rastlanan cevap, "riski seven" olmuştur. Katılımcıların büyük çoğunluğu risk vurgusu yaparak girişimci kişiliğin özellikle riski sevmesi gerekliliğini belirtmişlerdir. Bununla birlikte katılımclar girişimcilik kariyerini tercih edecek olan kişilerin girişken, azimli, sabırlı, tutkulu, özgüvenli, hırslı, dürüst, çalışkan ve meraklı olmaları gerektiğini belirt- 
mişlerdir. Çoğunlukla kendileri de bu özelliklere sahip olduklarını bildirmişlerdir. Fakat kendisinin örnek bir girişimci kişiliğe sahip olmadığını belirtenler de olmuştur. Kadın katılımcı 2'nin bu temadaki cevabı aşağıdaki gibidir.

"Bir girişimci istikrarl olmalı. Tuttuğunu koparabilmeli ve dış sese kapalı olmal. Kendime girişimcilik kapsamında 10 üzerinden puan verecek olsaydım 10 üzerine 3 verirdim. Kararlarımın arkasında sağlam duramadım. Bir kere özeleştiri yapmalı bir girişimci... (Kadın, 29, Ön lisans, Elazı̆̆)."

Katılımc karar alırken başkalarından etkilenilmemesi gerektiğinin altını çizmiş ve kendisinin bunu yapamadığ üzerinde durmuştur. Bu nedenle de girişimci bir kişilikten uzak olduğunu belirtmiştir. Görüşme esnasında bu konunun detaylandırılması istendiğinde, başkalarının kararlarını dinlediği için mevcut girişiminin yerinde saydığını, halbuki başkalarının sesine kulak vermeseydi şu an çok daha başarılı olabileceğini savunmuştur. Fakat bundan dersler çıkardığını ve bundan sonraki iş hayatında kararlarını daha bireysel vereceğini belirtmiştir.

Düzenleyici Tema 2- Başarma İhtiyacı: McClelland (1965) girişimcilik için önemli motivasyonlardan biri olarak başarma ihtiyacını işaret etmiştir. Bu bağlamda araştırmada bireyin içinden gelen bir diğer özellik olarak başarma ele alınmıştır. Bireyin sahip olduğu bu ihtiyacın onu girişimciliğe itip itmediği irdelenmiştir. Bu temada erkek katılımcı 8 'in cevabı aşağıdaki gibidir.

"Hayatta sorumluluklar başka sorumlulukları getiriyor. Ticaret hayatına girmeden başka bir firmada ücretli olarak çalıştığımda sorumluluğum tamamen kısmi ve kendimeydi. Ticaret hayatına başlamadan önce çalıştı̆̆ım firmalarda yaptı̆̆ım başarıları ispatlamam lazımdı ve yapamadı dememeleri için çok daha stresli ve gergindim ancak çok şükür başardım ve ispatladım. Sonralarn ise başarmmın sürekli olması için belki daha çok çalışma hissi duyuyorsun. Çünkü insanlar elindeki şeyleri kaybetmekten korkar ve önünüze hep yeni hedefler gelir onu da yapalım başarllım dersiniz. Zaten hayatın kendisi de öyle değil mi? Sürekli yaşamda yeni hedefler koyarak ilerlersiniz ve bu da belki yaşama amactnı oluyor. Bu söylediklerim illa maddi olarak anlaşılmasın başarnlar insanlarn yaşama bağlar (Erkek, 44, Ön lisans, Antalya)." 
Burada başlık altındaki görüşler neredeyse ikiye ayrılmış durumda. Katılımcların bazıları başarma ihtiyaçları nedeniyle girişimciliğe karar verdiklerini söylerken, yukarıdaki katılımcı gibi diğer kısmı da girişimci olduğu için kendini başarılı olmak zorunda hissettiğini belirtmiştir. Çok az sayıda katılımcı da hem işe başlamadan önce hem de girişimcilik kariyeri süresince başarma ihtiyacını sürekli hissettiğini belirtmiştir. Kadın girişimci 8 bu konuda şöyle bir cevap vermiştir:

"Başarn ve süreklilik ikisi birbirinden ayrlamaz bir ikilidir ancak hayatta her zaman stabil bir şekilde devamda etmeyebilir. Belirli dönemlerde inişler ve çıkışlar olmak zorundadır. Önemli olan bu süreçlerde ayakta kalabilmektir. Kendi açımdan her dönemde başarılı olmak isterim öncesi ve sonrasi yoktur. Önemli olan insanım hiçbir zaman hayat amaçlarını kaybetmemesi, hedeflerinin hep olması, yaşadı̆̆ınız başarısızlıklarda yeniden ayă̆a kalkılabilmeli çünkü başarının, kardeşi başarısızlıktır (Kadın, 42, Lisans, Ankara)."

Bu cevapların yanı sıra başarma ihtiyacı olmadığını belirten katılımcılar da olmuştur. Hatta girişimciliği tercih etmesinde kesinlikle bu ihtiyacın etkili olmadığını belirten kadın katılımcı 4, aşağıdaki gibi bir cevap vermiştir.

Benim için çok değişen bir şey olmadı. Kendime ait bir mimarlık ofisi açtım başkasının yanında çalışmaktansa bunu yaptım ve başarılıda oldum devamında. Ben belki kişilik olarak rahat birisi olduğum için başarı ve başarısızlık konularına çok takılmam. Sürekli başarı kavramı insanı yaşamında sımırlandırır. Inişler ve çıkışlar olmalı ve doğalıda budur. Tabi tam dipler ve tam çıkışları kast etmiyorum. Başarısızliğı görmezseniz, başarının anlamını ve önemini anlayamazsmız (Kadın, 32, Lisans, Antalya).

Özetle düzenleyici tema 2'deki yani başarma ihtiyacının girişimciliğe olan etkisindeki görüşler; "başarma ihtiyacının bireyi girişimciliğe ittiği", "girişimci olduğu için başarmak zorunda olduğu" ve "girişimcilik için başarma ihtiyacının gerekli olmadığı" şeklinde kümelenmiştir.

Düzenleyici Tema 3- Öz Yeterlilik: Öz yeterlilik, bir kişinin belirli bir görevi yerine getirme kabiliyetine olan inancıdır (Bandura, 1977). Kavram girişimcilik literatüründe yoğun şekilde tartışıldığı için girişimcilik öz yeterliliği şeklinde ele alınmaya başlamıştır. Girişimcilik öz yeterliliği genellikle; "bir insanın bir girişimi başlatmak ve yürütmek için özel görevleri başarıyla yerine 
getirme kabiliyetine güvenmesi" olarak tanımlanmıştır (Chen vd., 1998). Bu düzenleyici temada girişimcilik öz yeterliliğinin katılımclları ne oranda girişimciliğe sevk ettiğinin belirlenmesi hedeflenmiştir. Burada katılımclar girişimciliğin birçok konuda beceri isteyen bir iş olduğunu kabul etmiştir. Bunun sonucunda kendilerini bazı konularda yeterli görüp bazı konularda yetersiz görebildiklerini beyan etmişlerdir. Erkek katılımcı 2 ve 5 'in cevapları bu duruma iyi bir örnektir.

Ticaret hayatı sıkı takip, düzen, emek isteyen bir iştir. Ben de kendimi finansal bölümünde yetersiz gördüğ̈̈mü belirtmeliyim (Erkek, 26, Lisans, Antalya)."

"Başlarken bir yol haritam vardı. Çok beklenmedik bir duruma, beni sarsacak bir olayla tam anlamıyla karşılaşmadım. Ancak finans konusunda rakip, büyük firmalar karşısında insan bazen kendini yetersiz hissediyor (Erkek, 32, Lisans, Antalya)."

Katılımcıların kendilerini yetersiz hissettikleri konuların başında finans ve pazarlama gelmektedir. Bunun yanı sıra kadrolama, sektör bilgisi ve iş hayatında kadın olmanın zorluklarından ötürü kendilerini yetersiz gördüklerini belirten katılımcilar olmuştur. Bu durumun normal olduğunu kabul eden girişimciler, günümüzde bu yetersizlikleri aşmanın aslında kolay bir şey olduğunun da altını çizmişlerdir. Finans, pazarlama vb. konularda kurslara, seminerlere ve online kaynaklara yönelerek bu konudaki eksikliklerini giderdiklerini belirtmişlerdir. Bir kısmı ise eksik oldukları konularda profesyoneller istihdam ederek sorunu çözdüklerini söylemiştir.

Düzenleyici Tema 4- Kontrol Odağı: Kontrol odağı Rotter (1966)'a göre, bir kişinin elde ettiği ödülleri kendi davranış ve çabalarına bağlı görmesini sağlayan iç kontrol odağı ve bir kişinin elde ettiği ödülleri kendi benliği dışındaki güçlere bağlayan yani kendi eylemlerinden bağımsız olarak gerçekleştiğine

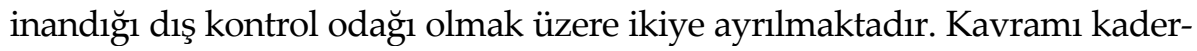
cilik ile de açıklayabiliriz. Başına gelen işlerden kaderi sorumlu tutmak veya kendi yaptıklarına bağlamak Anadolu kültüründe görülen en yaygın davranış şekilleridir (Orhan, 2017). Hofstede ve Minkov'un (2010) kültürel boyutlar çalışması, Türkiye'deki kültürün "kısa dönem eğilimli" olduğunu göstermiştir. Bu durum da uzun vadeli planlar yapılmayan ve belirli bir noktadan sonra akışı kadere bırakan bir yapıda olduğumuzun kanıtı niteliğindedir. 
Kontrol odağının girişimcilik açısından büyük bir önemi vardır çünkü çoğu zaman girişimcilerin düştüğü yerden kalkmasına veya pes etmesine neden olabilmektedir. Bu nedenle kavram girişimcilerin gözünden değerlendirilmiştir. Bu konudaki görüşler genellikle, girişimcilerin karşılaştıkları sonuçların kendi yaptıklarına bağladıkları üzerinedir. Bu durumda girişimcilerde genel toplumsal yapının aksine iç kontrol odağının hâkim olduğunu savunmak mümkündür. Bu noktada erkek katılımc1 9 ve kadın katılımc 3'ün cevapları büyük oranda katılımcıların görüşünü ortaya koymaktadır.

"Kaderci bir yapıya sahip değilim. İnsanlarm yaşamlarmdaki en kolay şey başarısızlıklarını kadere bağlamaktır (Erkek, 44, Lisans, İstanbul)."

"İkisinin bir arada olduğuna inanan birisiyim. Kadere inancım tabi var ama hiçbir şey yapma, çalışma armut piş ă̆zıma düş anlayışıyla da olmaz. Hep şunu deriz tedbir sizden, takdir Allah'tandır. Sen öncelikle çabalayıp bir şeyler yapacaksin ve ondan sonra olanı Rabbime bırakacaksın. Şöyle bir hikâye var: Adamın biri sürekli dua eder lütfen bana milli piyango çıksın diyerek. Sürekli aynı duayı eder durur. Ama bir türlü duası kabul olmaz. En sonunda meleklerden birisi sorar Allah'ım neden bu adamin duasın kabul etmezsiniz? Edeceğim, edeceğim de yalnı adam bir bilet alsa. Yani Rabbimizden isterken bir şeyler o yolda çalışmalıyız, çabalamalıyız (Kadın, 42, Lisans, Ankara)."

Cevaplardan da anlaşılacağı üzere katılımclların büyük çoğunluğu başarılarının kendi çabalarına bağlı olduğunu düşünmektedir. Kimi kader inancına sahip olmadığı için böyle düşünürken, diğerleri kadere mutlaka inand1ğını belirtip ticari hayattaki başarının veya başarısızlığın kaderle açıklanamayacağının altını çizmiştir.

Global Tema 2- Dışsal Faktörler: Bireyleri girişimciliğe iten içsel faktörlerin ardından girişimcilerin gözünden çevresel faktörler de ele alınmaya çalışılmıştır. Dışsal faktörleri ortaya koymaya yönelik oluşan düzenleyici temalar; sermayeye ulaşım, sektör bilgisi, sosyal çevre ve girişimcilik eğitimleridir. Katılımcıları girişimciliğe iten çevresel faktörleri ortaya koymak için yöneltilen başlıca sorulara yönelik cevaplar aşağıdaki düzenleyici temaları oluşturmuştur. 
Düzenleyici Tema 1- Sermayeye Ulaşım: Araştırmacılar, bireylerin girişimcilik kariyerini tercih etmesinde veya girişimci olmak istememesinde önemli rol oynayan unsurlardan biri olarak sermayeye erişimi göstermektedir (S. Coleman, 2000; Steel, 1994). Sermayeye erişim konusunda sorular sorulara verilen cevaplar içerisinde en sık rastlanan sermaye temin yöntemleri; aileden temin, banka kredisi, KOSGEB girişimcilik desteği, arkadaş çevresinden borç alma ve kendi birikimleri olarak karşımıza çıkmaktadır. Hemen her katılımcı giriş aşamasında sermaye bulmanın büyük sorun olduğunu belirtmiştir. Ayrıca bir işi yapmaya gerçekten istekli olunduğunda sermayenin bir şekilde bulunabileceğinin de altını çizmiştir. Bu konuda erkek katılımcı 7 sermayeyi nasıl bulduğunu aşağıdaki gibi açıklamıştır.

“Kendime ait küçük bir sermayem vard. Bununla birlikte KOSGEB'ten aldiğım hibe desteği yeterli oldu... İlk etapta aldığım bazı ürünlerde peşin ödeme yapmayı belirli taksitlerde borçlanarak ödeme yaptım. Böylece kuruluş aşamasındaki ă̆ır sermaye ihtiyacın zamana bölmüş̧ oldum (Erkek, 25, Lisans, Antalya)."

Dïzenleyici Tema 2- Sektör Bilgisi: Özellikle rekabet avantajı sağlayabilmek için bir işe başlamadan önce sektör, pazar ve işin işleyişiyle ilgili bilgilere çok ihtiyaç duyulmaktadır. Başka bir deyişle girişimcilik kararı bilişsel süreçlerden geçilerek alındığı için pazar fırsatları ancak doğru bilgiyle yakalanabilmektedir (Sesen, 2013). Bu kısımda girişimcilerin kuruluş aşamasında doğru bilgiye ulaşma konusundaki sıkıntıları irdelenmeye çalışılmıştır. Bu konuda girişimciler bilgiye erişim konusunda çok fazla zorlanmadıklarını belirtmişlerdir. Özellikle daha önce aile bireyleri içerisinde benzer sektörlerde faaliyette bulunan işyeri sahipleri olan girişimciler sektör konusunda daha rahat olduklarını belirtmişlerdir. İş açılışı esnasındaki prosedürler konusunda ise danışmanlık alarak daha rahat bir kuruluş evresi geçirdiklerini belirten girişimciler olmuştur. Ayrıca sektörü yakından tanıyan ortakları sayesinde daha rahat bilgi akışına sahip olduğunu belirten girişimciler de olmuştur. Bu konuda kadın katılımcı 2'nin görüşleri aşağıdaki gibidir.

"Başlamadan önce çok araştırma yaptım, bilgiye ulaşmada hiç sorun yaşamadım. Bu konuda tüm bilgi sahibi olan değerli insanlar da çok yardımon oldular. Bu yetti mi? Yetmedi ama idare etti. Tabi en son edindiğim bilgiler üzerine gözlem yöntemiyle istediğim araştırmayı yaptım ve istediğim să̆lıklı bilgiyi yine kendim elde ettim (Kadın, 29, Ön lisans, Elazığ)." 
Sektörün zorluk derecesine göre sorun yaşadığını belirten katılımcılar da olmuştur. Bu konuda özellikle uzay ve havacılık alanında üretim yapan girişimcilerden K3 aşağıdaki gibi görüş belirtmiştir.

"Uzay ve havaculık sektörünü Türkiye'de cidden çok kapalı kutu olarak ifade edebilirim. Kesinlikle hiçbir kurum kolay kolay bilgi paylaşımı yapmıyor ve bu da bizim için problem teşkil etti. Zaten bu alanda pazara girme noktasinda da epey sıkıntı çektik. Dar bir çerçeve olduğu için kimse sizi sokmak istemiyor. Aslında pasta çok büyük kendilerinin yediŏi dilim en fazla \%40'lık bir dilimdir. Geriye kalan kısmı maalesef ithalat vb. yollarla să̆lanmakta. İşte bizde buna engel olmak için bu işe koyulduk. Bu alanda profesyonel olarak fizibilite çalışmaları yaptırdık ve ona göre bir iş planı hazırladık. Akademi dünyasında bu alanda çalışmaları olan Türkiye'nin en önemli hocalarıla istişareler yaparak onlardan danışmanlık hizmetleri ald $\_$ve hala almaya devam etmekteyiz. Yine finansal konularda, proje, fizibilite hazırlama, KOSGEB vb. danışmalık hususlarında ise alanında uzman kişilerden danışmanlık hizmetleri aldım ve hala çalışmalarımı beraber devam etmektedir. Hayallerimizi, yapmak istediklerimizi devlet büyüklerimize anlattım ve bir kadın girişimci olarak çok şükür takdirlerini alarak belirli konularda bize yol gösterip yardımoı oldular (Kadın, 42, Lisans, Ankara)."

Zor bir sektörde faaliyet gösterse de akademiden ve profesyonel danışmanlıklarla sorunları aştığını belirten katılımcı, işin karmaşıklaştıkça veya spesifikleştikçe sektör bilgisinin zorlaştığını kanıtlamıştır. Bu durum basit bir unsur gibi görünse de nitelikli ve yüksek katma değerli işlerde gayet önemli bir etmen olarak karşımıza çıkmaktadır. Bu nedenle herkesin yapabileceği klasik işlerin dışında özellikle ileri teknoloji gerektiren girişimleri başlatmak için ciddi bir bilgi akışına ihtiyaç duyulduğu bilinmelidir. Buna rağmen çağımız dijital çağ veya bilgi çağı olarak adlandırılmaktadır. Doğru bir strateji belirlendiğinde her türlü bilgiye ulaşmanın mümkün olabileceğini belirtmekte yarar vardir.

Düzenleyici Tema 3- Sosyal Çevre: Sosyal ağlar denilince akla her ne kadar ilk olarak sosyal çevre gelse de formel ve informel ağların yeni girişim oluşturmayı desteklemek ve teşvik etmek için kritik öneme sahip olduğu bilinmelidir (Neck vd., 2004). Sadece yakın çevrenin ötesinde bir sistemi kapsayan bu başlık bu doğrultuda incelenmeye çalışılmıştır. Fakat katılımcılar özellikle 
yakın çevrelerinin etkisi üzerinde durmuştur. Kültürel olarak ülkemizde yakın çevrenin bireyler üzerindeki etkinliği düşünüldügünde bu durum kaç1nılmaz olmuştur. Burada bireyler olumlu ve olumsuz tepkiler aldıklarını belirtmişlerdir. Ayrıca olumsuz tepkilere kulak asmadıklarını ve kimsenin onları girişimcilik yapma arzusundan vazgeçiremediğini belirtmişlerdir. Konuyla ilgili erkek katılımcı 5 ve kadın katılımcı 7'nin görüşleri aşağıdaki gibidir.

"Ailem öncelikle okulu halletmemi söylemelerine rağmen benim kararl olduğumu görünce ve iş fikrimin de uygun olduğunu gördüklerinden destek oldular. Ancak çeorede arkadas ya da diğerlerinin tepkisi bazılarının olumlu bazlarm ise "sen yapamazsin, olmaz bu iş, ticaret göründüğü kadar basit değil vb." ş̧ekilde olumsuz olduğunu gördüm... (Erkek, 32, Lisans, Antalya)."

"Tabi ufak tefek, olumlu olumsuz tepkiler aldım. Özellikle eşimin ailesinden ve çeoresinden tepkiler aldım. Kadın başına bir işletme kuramayacağımı söylediler. Dominant bir yapıya sahip olduğumdan kimseyi dinlemedim ve işyerimi açtım. İyi ki de yapmışım (Kadın, 60, Lise, Osmaniye)."

Düzenleyici Tema 4- Girişimcilik Eğitimi: Girişimcilik eğitimi temelde girişimcilik için çok önemli olan kişisel niteliklerin, tutumların ve becerilerin geliştirilmesini kapsamaktadır (Fayolle ve Gailly, 2008). Son yıllarda özellikle eğitim sayesinde bireylerin girişimciliğe sevk edilebileceği fikri büyük önem kazanmıştır. Başka bir deyişle "girişimci doğulmaz, girişimci olunur" tarzında bir eğilim söz konusudur. Bu durumu katılımclara sorduğumuzda büyük oranda eğitimin girişimciliği tercih etmede önemli bir unsur olduğunu belirttiklerini gördük. Konuyla ilgili kadın girişimcilerden 6'nın görüşü aşağdaki gibidir.

"Elbette. Yukarıda bahsettiğim üzere öncesindeki eğitimler motivasyonumu sağladı. Sonrasında da lisans tamamlama ve yüksek lisans, iş kolundaki yeni fikirleri beraberinde kendiliğinden getirdi (Kadın, 45, Lisans, Malatya)."

Bunun yanı sıra eğitimlerden etkilenmediğini, girişimcilik kariyerini tercih etmede temel motivasyonunun diğer unsurlar olduğunu belirten girişimciler de olmuştur. Bu duruma örnek teşkil eden erkek katılımcı 4'ün cevabı aşağıdaki gibidir. 
“Üniversite, KOSGEB eğitimi vb.den veya herhangi başka bir kimseden etkilenmedim. Bu kariyeri seçmemde daha fazla para kazanabilme isteğim en büyük motivasyonum oldu benim (Erkek, 39, Lise, Antalya)."

Global Tema 3- Güçlï Faktör: Bütün unsurlar bir arada düşünüldüğünde bireyleri girişimciliğe iten temel unsurun ne olduğunu ortaya koymaya yönelik sorduğumuz sorulara göre içsel faktörlerin çok büyük bir üstünlüğe sahip olduğunu gördük. Burada cinsiyet açısından da bir karşılaştırma yapmanın uygun olacağına karar verdik.

Erkek katılımcılardan dördü onları girişimciliğe iten temel faktör olarak kişilik özelliklerine işaret etmiştir. İkisi sahip oldukları ideallerin, hayallerin ve hedeflerin onları girişimci yaptığını belirtmiştir. Biri ise başarma ihtiyacının onu girişimciliğe iten faktör olduğunu söylemiştir. Böylece dokuz erkek katılımcıdan yedisi, onları girişimciliğe iten faktörün içsel faktörler olduğunu beyan etmiştir. Kalan ikisinden birisi çevre ve ailenin teşvikiyle girişimci olduğunu diğeri ise sektörle ilgili sahip olduğu geniş bilginin onu girişimciliğe ittiğini söylemiştir. Böylece yedi katılımcı onları girişimciliğe iten faktör olarak içsel faktörleri işaret ederken, iki katılımcı ise dışsal faktörleri üstün görmüştür.

Kadın girişimciler açısından da durum pek farklı değildir. İki katılımcı, öz yeterliliklerinin olduğunu düşündükleri için girişimci olduklarını söylemişlerdir. Bir katılımcı kişilik özelliklerinin, bir katılımc ise başarma ihtiyacının onları girişimciliğe ittiğini bildirmiştir. Aynı şekilde bir katılımcı da ideallerinin onu girişimciliğe ittiğine dikkat çekmiştir. Ayrıca bir katılımcı gördüğü eğitimin onu girişimci yaptığını belirtirken bir katılımcı da hem aldığı eğitimin hem de ailesinin desteğinin onu girişimci yaptığının altını çizmiştir. Böylece kadın katılımclarda da durum beşe iki içsel faktörlerin lehinedir.

\section{Tartışma ve Sonuç}

Girişimcilik birçok yönüyle ülke ekonomileri için oldukça önemlidir. Girişimciler üstlendikleri istihdam ve katma değer sağlama, yeni pazarlar yaratma, kalkınmaya katkıda bulunma, teknoloji geliştirme gibi fonksiyonlar sayesinde adeta ülke ekonomisi içerisinde işleyen çarkların birer parçası konumundadır. Yerine getirdikleri bu işlevler, girişimcilik faaliyetlerini akademi 
çevrelerince de her daim cazip ve incelemeye değer kılmıştır. Böylece girişimcilikle ilgili konular değişik perspektiflerden sürekli incelenmiştir. Biz de bu araştırmada girişimcileri yaptıkları işe iten nedenleri tartışmaya, irdelemeye ve girişimcilerin gözünden ele almaya çalıştık. Bu amaç doğrultusunda nitel bir araştırma gerçekleştirdik. Araştırmaya veri toplamak amacıyla Türkiye'nin çeşitli bölgelerinden girişimcilerle görüşmeler gerçekleştirip, onlardan samimi cevaplar aldık.

Yapılan araştırma sonucunda kişilik özelliklerinin girişimcilik kariyerini seçmede en önemli unsur olduğu görülmüştür. Katılımclardan çoğu, kendilerini girişimciliğe iten unsur olarak sahip oldukları kişiliği işaret etmiştir. Cinsiyet açısından bakıldığında bu durumun erkeklerde daha fazla olduğu görülmüştür. Başka bir deyişle erkeklerin çoğunluğu onları girişimciliğe iten unsurun kişilik özellikleri olduğunu belirtmiştir. Araştırmanın en çarpıcı sonucu olarak bu bulgu gösterilebilir. Çünkü araştırmanın temel amaçlarından biri bireyleri girişimciliğe iten faktörler arasından hangisinin daha güçlü olduğunu ortaya koymaktı. Bu durumda kişilik özelliklerinin bu alanda zirveyi ele geçirdiğini belirtmek gerekir. Çalışmanın bu bulgusu literatürde daha önce farklı kültürlerde yapılan araştırmalarla (Crant, 1996; Gadar ve Yunus, 2009; Jing ve Sung, 2012; Taormina ve Kin-Mei Lao, 2007) benzerlik göstermektedir.

İlhan (2003) girişimciliği etkileyen tek bir unsur olamayacağını belirtmiştir. Ayrıca içsel ve çevresel faktörlerin bir arada bireyleri girişimciliğe ittiğinin altını çizmiştir. Çalışmanın bulguları bu tespiti doğrulamıştır. Literatürde sıkça ele alınan içsel ve çevresel faktörler görüşme gerçekleştirilen girişimcileri bu kariyeri seçmeye iten faktörler olarak göze çarpmıştır. Burada diğer çalışmalardan ayrışan nokta ise kişilik özelliklerinden sonra en çok girişimciliğe iten faktör olarak idealler ve hayallerin olmasıdır. Literatürde ele alınan faktörler içerisinde idealler veya hayallerin incelenmemesi bu durumu kanitlamıştır. Bu yönüyle çalışma ilgili literatüre katkıda bulunmuştur. Buradan hareketle gelecek çalışmalar için girişimciliğe iten faktörler içerisinde ideallerin ayrıca incelenmesi tavsiye edilebilir.

Öz yeterlilik girişimcilik açısından oldukça önemli bir unsur olarak görülmektedir (McGee ve Peterson, 2019; McGee vd., 2009; Wilson vd., 2007; Zhao vd., 2005). Araştırmamızda, girişimcilerin gözünden en önemli üçüncü unsurun öz yeterlilik olduğu sonucuna ulaşılmıştır. Burada dikkat çeken nokta ise 
sahip oldukları öz yeterliliğin onları girişimci yaptığını belirten bireylerin tümünün kadın olmasıdır. Ayrıca kadınları girişimciliğe iten unsur olarak en fazla öz yeterlilik algısı göze çarpmıştır. Ülkemizde kadın olmanın iş hayatındaki zorlukları düşünüldüğünde kadın girişimcilerin ciddi bir kendini yeterli hissetmeden girişimciliğe kalkışmayacağı aşikardır. Cohoon vd. (2010) başarılı kadın girişimcilerin erkeklerden farklı olduklarını savunmuşlardır. Elde ettiğimiz bulgularda bu görüşü destekler niteliktedir.

Girişimciliği etkileyen çevresel faktörlerin başında sosyal çevre gelmektedir. Özellikle girişimcilik geçmişi olan bir aileden gelen bireylerin girişimciliğe daha yatkın oldukları görülmektedir. İkinci sırada ise gördükleri eğitimin onları girişimci yaptığı görüşü ağır basmıştır. Buradaki durum literatürde sıkça işlenen (Balaban ve Özdemir, 2008; Çiçek, 2016; Kuratko, 2005; Robinson ve Haynes, 1991) girişimcilik eğitiminden farklıdır. Literatürde girişimcilik eğitiminin bireyleri girişimciliğe iteceği üzerinde durulurken, çalışmamızda bu durumdan farklı bir tablo ortaya çıkmıştır. Katılımcılar aldıkları girişimcilik eğitiminden ziyade aldıkları eğitimin doğası gereği girişimci olduklarını belirtmişlerdir. Başka bir deyişle sahip oldukları eğitimle girişimcilikten başka bir şey yapamayacakları için girişimci oldukların söylemişlerdir.

Çalışmanın birtakım sınırlılıkları da bulunmaktadır. Öncelikle görüşülen kişilerin ülkenin her yerinden olmayışından ötürü bulguların ilgili literatür ve Türk kültürü açısından bir genellenebilirlik problemine yol açacağ düşünülmektedir. Sonuçların genellenebilmesi için daha büyük bir katıl1mın söz konusu olması gerektiği düşünülmektedir. Bu bağlamda gelecek çalışmalarda tüm değişkenlerin bir arada daha geniş katılıma olanak sağlayan nicel bir araştırma ile tekrar incelenmesi önerilebilir. Diğer bir sınırlılık ise her ne kadar mülakat esnasında oldukça samimi bir ortam oluşsa da kendileriyle ilgili bazı konularda katılımcıların dürüst olamama endişesidir. Benzer şekilde sınırları belli bir nicel çalışma ile bu durumun da aşılabileceği düşünülmektedir. 


\title{
EXTENDED ABSTRACT
}

\section{Internal and External Factors Affecting Entrepreneurship from the Eyes of Entrepreneurs}

\author{
Berat Çiçek - Yusuf Emre Karakaş \\ Muş Alparslan University, Malatya Turgut Özal University
}

Entrepreneurship is a major source of employment, economic growth and technological development (Kuratko, 2007). According to world-wide researches, unemployment levels of regions with an increase in entrepreneurship rates are decreasing rapidly (Audretsch et al., 2002). However, there is still poor demand for entrepreneurship (Liñán et al., 2011). For instance, it has been reported that even less than $10 \%$ of the adult population starts entrepreneurship activities in OECD countries (Athiyaman et al., 2007). Therefore, there is a wide-ranging agreement in the literature on the importance of encouraging entrepreneurship to promote economic development and employment creation (Mitra, 2008).

Entrepreneurship is considered as an important concept in terms of the important missions it carries and the benefits it provides to the societies, however it is a subject of continuous research and discussion. One of the important debates on entrepreneurship has been the factors that push individuals to entrepreneurship, and no one has reached a definite conclusion on these factors (Busenitz et al., 2003). In this context, especially cognitive approaches began to be prominent (Baron, 2004; Gatewood et al., 1995). According to this approach, it is argued that entrepreneurship is a tendency towards the functioning of intelligence (Izquierdo and Buelens, 2011; Krueger Jr et al., 2000). On the other hand, it is still widely believed that personality traits and demographic characteristics have a serious impact on entrepreneurship (Mazzarol et al., 1999; Rauch and Frese, 2007).

In this point, there are two conclusions. While some researchers (Thompson, 1999) argue that entrepreneurship is a behavior that comes from within the individual and thus pushes people to engage in entrepreneurship; other researchers (Kuratko, 2005; Peterman and Kennedy, 2003) underlined that entrepreneurship is a learnable phenomenon. For these reasons, the causes why individuals choose an entrepreneurial career need to be clarified. 
Although there is a lot of discussion in the literature, there is still a big gap regarding the factors affecting entrepreneurship. In this context, the main objective of this study is to reveal the reasons that push entrepreneurs to entrepreneurship. While previous studies on this subject have taken a specific factor that affects entrepreneurship, in spite of that in this study, internal and external factors were tried to be examined together. Thus, it is the main purpose of this study to reveal the pioneers that push individuals to entrepreneurship career. However, earlier exploratory researches focused on individuals who prefer to pursue an entrepreneurial career. Another unique aspect of this study is that the research is done to individuals who are already entrepreneurs.

The study consists of two parts. The first part consists of literature review. In the literature review, internal (need for success, locus of control, self-efficacy) and external (access to capital, knowledge of work and sector, social environment, entrepreneurship education) factors affecting entrepreneurship are examined. In addition to the first part of the literature review, this paper also has a research section for the analysis of data obtained through interviews based on semi-structured questions and interviews. Thus, from the perspective of entrepreneurs, the antecedents that pushed them to this career were examined from primary sources. In this context, the study is expected to reveal which factors are superior to determine entrepreneurship.

For this purpose, a qualitative research was conducted. In this context, depth interviews were made with 16 entrepreneurs owning workplaces in various provinces of Turkey, 9 of whom are males and 7 of whom are females. During the interviews, a formerly prepared questionnaire consisting of 10 semi-structured questions was used. The data were analysed by NVivo package program according to thematic network analysis method.

According to the findings of the study, internal factors and external factors play a role among the factors that push individuals to entrepreneurship. However, internal factors were found to be more effective. Especially personality traits were determined to be the most important factor in choosing the entrepreneurship career. It is concluded that self-efficacy is another factor that pushes individuals to entrepreneurship. The point that draws attention here is that all individuals who stated that their self-efficacy makes them entrepreneurs are women. Also, self-efficacy perception was the most important factor that pushed women to entrepreneurship. 
The social network is one of the leading environmental factors affecting entrepreneurship. In particular, individuals from a family with an entrepreneurial background are more likely to be entrepreneurs. Secondly, their education made them entrepreneurs. The discovery that ideals and dreams are factors that push individuals to entrepreneurship has made a unique contribution to the literature by this study. From this point of view, this paper may advise examining ideals separately among the factors that push entrepreneurship for future studies.

\section{Kaynakça / References}

Acs, Z. J., Arenius, P., Hay, M., ve Minniti, M. (2005). Global entrepreneurship monitor: 2004 executive report. Retrieved from UK:

Acs, Z. J., ve Audretsch, D. B. (2003). Introduction to the handbook of entrepreneurship research. In Handbook of entrepreneurship research (pp. 3-20): Springer.

Ajzen, I. (2002). Perceived behavioral control, self-efficacy, locus of control, and the theory of planned behavior 1. Journal of applied social psychology, 32(4), 665-683.

Akhmetshin, E. M., Romanov, P. Y., Zakieva, R. R., Zhminko, A. E., Aleshko, R. A., ve Makarov, A. L. (2019). Modern Approaches to Innovative Project Management in Entrepreneurship Education: A Review of Methods and Applications in Education. Journal of Entrepreneurship Education, 22, 1-15.

Asante, E. A., ve Affum-Osei, E. (2019). Entrepreneurship as a career choice: The impact of locus of control on aspiring entrepreneurs' opportunity recognition. Journal of Business Research, 98, 227-235.

Athiyaman, A., Dabson, B., Hamm, G. F., Henderson, J., Holley, J., Hustedde, R., Loveridge, S. (2007). Entrepreneurship and local economic development: Lexington Books.

Attride-Stirling, J. (2001). Thematic networks: An analytic tool for qualitative research. Qualitative research, 1(3), 385-405.

Audretsch, D. B., Thurik, R., Verheul, I., ve Wennekers, S. (2002). Entrepreneurship: determinants and policy in a European-US comparison (Vol. 27): Springer Science \& Business Media.

Balaban, Ö., ve Özdemir, Y. (2008). Girişimcilik eğitiminin girişimcilik eğilimi üzerindeki etkisi: Sakarya üniversitesi İ̈BF örneği. Girişimcilik ve Kalkınma Dergisi, 32, 133-147. 
Bandura, A. (1977). Self-efficacy: toward a unifying theory of behavioral change. Psychological review, 84(2), 191.

Barbosa, S. D., Gerhardt, M. W., ve Kickul, J. R. (2007). The role of cognitive style and risk preference on entrepreneurial self-efficacy and entrepreneurial intentions. Journal of Leadership E Organizational Studies, 13(4), 86-104.

Baron, R. A. (2004). The cognitive perspective: a valuable tool for answering entrepreneurship's basic "why" questions. Journal of business venturing, 19(2), 221-239.

Bates, T. (1985). Entrepreneur human capital endowments and minority business viability. Journal of Human Resources, 20(4), 540-554.

Baum, J. R., Frese, M., ve Baron, R. A. (2014). Born to be an entrepreneur? Revisiting the personality approach to entrepreneurship. In The psychology of entrepreneurship (p. 73-98): Psychology Press.

Becker, G. S., Murphy, K. M., ve Tamura, R. (1990). Human capital, fertility, and economic growth. Journal of political economy, 98(5, Part 2), S12-S37.

Blanchflower, D. G., ve Oswald, A. J. (1998). What makes an entrepreneur? Journal of labor Economics, 16(1), 26-60.

Blawatt, K. (1995). Defining the entrepreneur: a conceptual model of entrepreneurship. CCSBE-CCPME Proceedings, 13-37.

Boyd, N. G., ve Vozikis, G. S. (1994). The influence of self-efficacy on the development of entrepreneurial intentions and actions. Entrepreneurship Theory and Practice, 18(4), 63-77.

Bradley, D. E., ve Roberts, J. A. (2004). Self-employment and job satisfaction: investigating the role of self-efficacy, depression, and seniority. Journal of small business management, 42(1), 37-58.

Brandstätter, H. (2011). Personality aspects of entrepreneurship: A look at five meta-analyses. Personality and individual differences, 51(3), 222-230.

Brass, D. J. (1992). Power in organizations: A social network perspective. Research in politics and society, 4(1), 295-323.

Brockhaus, R. H. (1975). IE locus of control scores as predictors of entrepreneurial intentions. Paper presented at the Academy of Management Proceedings.

Burns, P. (2016). Entrepreneurship and small business: Palgrave Macmillan Limited.

Busenitz, L. W., West III, G. P., Shepherd, D., Nelson, T., Chandler, G. N., ve Zacharakis, A. (2003). Entrepreneurship research in emergence: Past trends and future directions. Journal of management, 29(3), 285-308. 
Carraher, S. M., Buchanan, J. K., ve Puia, G. (2010). Entrepreneurial need for achievement in China, Latvia, and the USA. Baltic Journal of Management, 5(3), 378-396.

Charoensukmongkol, P. (2019). The Moderating Effect of Locus of Control on the Relationship between Perceived Poor Business Performance and Superstitious Behaviors of Thai Entrepreneurs. BU Academic Review, 18(1), 1-17.

Chen, C. C., Greene, P. G., ve Crick, A. (1998). Does entrepreneurial self-efficacy distinguish entrepreneurs from managers? Journal of business venturing, 13(4), 295-316.

Chowdhury, S., Endres, M. L., ve Frye, C. (2018). The influence of knowledge, experience, and education on gender disparity in entrepreneurial self-efficacy. Journal of Small Business \& Entrepreneurship, 31(5), 371-389.

Clercq, D. D., ve Arenius, P. (2006). The role of knowledge in business start-up activity. International Small Business Journal, 24(4), 339-358.

Cohoon, J. M., Wadhwa, V., ve Mitchell, L. (2010). Are successful women entrepreneurs different from men? Available at SSRN 1604653.

Coleman, J. S. (1988). Social capital in the creation of human capital. American journal of sociology, 94, S95-S120.

Coleman, S. (2000). Access to capital and terms of credit: A comparison of menand women-owned small businesses. Journal of small business management, 38(3), 37.

Collins, C. J., Hanges, P. J., ve Locke, E. A. (2004). The relationship of achievement motivation to entrepreneurial behavior: A meta-analysis. Human performance, 17(1), 95-117.

Cope, J., Jack, S., ve Rose, M. B. (2007). Social capital and entrepreneurship: An introduction. International Small Business Journal, 25(3), 213-219.

Crant, J. M. (1996). The proactive personality scale as a predictor of entrepreneurial intentions. Journal of small business management, 34, 42-49.

Creswel, J. W. (2009). Research design: Qualitative, quantitative, and mixed methods approaches. Los angeles: University of Nebraska-Lincoln.

Cunningham, J. B., ve Lischeron, J. (1991). Defining entrepreneurship. Journal of small business management, 29(1), 45-61.

Çiçek, B. (2016). Girişimcilik dersinin öğrencilerin girişimcilik eğilimi üzerindeki etkisi: Muş Alparslan Üniversitesi İIBF'de bir araştırma. Paper presented at the International Conference on Quality in Higher Education, Sakarya-TURKEY, November. 
Çiçek, B. (2018). Social media entrepreneurship (Sosyal medya girişimciliği). İctimaiyat Sosyal Bilimler Dergisi, 2(1), 10-17.

Çiçek, B., ve Aknar, A. (2019). Kişilik özelliklerinin tükenmişlik ve presenteizm davranışları üzerindeki etkisi. Üçüncü Sektör Sosyal Ekonomi Dergisi, 54(3), 1234-1258.

Çiçek, B., ve Karakaş, Y. E. (2015). Girişimcilik eğitimi alan adayların kurumsallaşma algısını ölçmeye yönelik bir araştırma. Turgut Özal Uluslararası Ekonomi ve Siyaset Kongresi, 3, 11-13.

Dakhli, M., ve De Clercq, D. (2004). Human capital, social capital, and innovation: a multi-country study. Entrepreneurship \& regional development, 16(2), 107128.

Davidsson, P., ve Honig, B. (2003). The role of social and human capital among nascent entrepreneurs. Journal of business venturing, 18(3), 301-331.

Douglas, E. J., ve Shepherd, D. A. (2002). Self-employment as a career choice: Attitudes, entrepreneurial intentions, and utility maximization. Entrepreneurship Theory and Practice, 26(3), 81-90.

Easterby-Smith, M., Thorpe, R., ve Jackson, P. R. (2012). Management research: Sage.

Embi, N. A. C., Jaiyeoba, H. B., ve Yussof, S. A. (2019). The effects of students' entrepreneurial characteristics on their propensity to become entrepreneurs in Malaysia. Education+ training.

Eryılmaz, M. E. (2011). Yeni kurumsalcı örgüt kuramı perspektifinden İlköğretim örgütsel alanında yaşanan kurumsal değişim ve nedenleri. Middle East Technical University Studies in Development, 38(3).

Fayolle, A., ve Gailly, B. (2008). From craft to science: Teaching models and learning processes in entrepreneurship education. Journal of European industrial training, 32(7), 569-593.

Gadar, K., ve Yunus, N. K. Y. (2009). The influence of personality and socio-economic factors on female entrepreneurship motivations in Malaysia. International review of business research papers, 5(1), 149-162.

Galloway, L., ve Brown, W. (2002). Entrepreneurship education at university: a driver in the creation of high growth firms? Education+ training, 44(8/9), 398-405.

Gatewood, E. J., Shaver, K. G., ve Gartner, W. B. (1995). A longitudinal study of cognitive factors influencing start-up behaviors and success at venture creation. Journal of business venturing, 10(5), 371-391. 
Giné, X. (2011). Access to capital in rural Thailand: An estimated model of formal vs. informal credit. Journal of Development Economics, 96(1), 16-29.

Glaser, B. G., ve Strauss, A. L. (2017). Discovery of grounded theory: Strategies for qualitative research: Routledge.

Greve, A., ve Salaff, J. W. (2003). Social networks and entrepreneurship. Entrepreneurship Theory and Practice, 28(1), 1-22.

Guest, G., Bunce, A., ve Johnson, L. (2006). How many interviews are enough? An experiment with data saturation and variability. Field methods, 18(1), 59-82.

Gürol, Y., ve Atsan, N. (2006). Entrepreneurial characteristics amongst university students: Some insights for entrepreneurship education and training in Turkey. Education+ training, 48(1), 25-38.

Hansemark, O. C. (1998). The effects of an entrepreneurship programme on need for achievement and locus of control of reinforcement. International Journal of Entrepreneurial Behavior \& Research, 4(1), 28-50.

Hansen, E. L. (1995). Entrepreneurial networks and new organization growth. Entrepreneurship Theory and Practice, 19(4), 7-19.

Haynie, J. M., Shepherd, D., Mosakowski, E., \& Earley, P. C. (2010). A situated metacognitive model of the entrepreneurial mindset. Journal of business venturing, 25(2), 217-229.

Hoang, H., ve Antoncic, B. (2003). Network-based research in entrepreneurship: A critical review. Journal of business venturing, 18(2), 165-187.

Hofstede, G., ve Minkov, M. (2010). Long-versus short-term orientation: New perspectives. Asia Pacific business review, 16(4), 493-504.

Hynes, B. (1996). Entrepreneurship education and training-introducing entrepreneurship into non-business disciplines. Journal of European industrial training, 20(8), 10-17.

İlhan, S. (2003). Sosyo-Ekonomik Bir Fenomen Olarak Girişimciliğin Oluşumunu Etkileyen Başlıca Faktörler. Muğla Üniversitesi Sosyal Bilimler Enstitüsü Dergisi(11), 61-79.

Isenberg, D. J. (2010). How to start an entrepreneurial revolution. Harvard Business Review, 88(6), 40-50.

Izquierdo, E., ve Buelens, M. (2011). Competing models of entrepreneurial intentions: The influence of entrepreneurial self-efficacy and attitudes. International Journal of Entrepreneurship and Small Business, 13(1), 75-91. 
Jing, L.-L., ve Sung, M. (2012). University students personality traits and entrepreneurial intention: Using entrepreneurship and entrepreneurial attitude as mediating variable. International Journal of Economic Research 3 (3), 76-82.

Judge, T. A., Erez, A., Bono, J. E., ve Thoresen, C. J. (2002). Are measures of selfesteem, neuroticism, locus of control, and generalized self-efficacy indicators of a common core construct? Journal of personality and social psychology, 83(3), 693.

Katz, J. A. (2003). The chronology and intellectual trajectory of American entrepreneurship education: 1876-1999. Journal of business venturing, 18(2), 283-300.

Kristiansen, S., ve Indarti, N. (2004). Entrepreneurial intention among Indonesian and Norwegian students. Journal of Enterprising Culture, 12(01), 55-78.

Krueger Jr, N. F., Reilly, M. D., ve Carsrud, A. L. (2000). Competing models of entrepreneurial intentions. Journal of business venturing, 15(5-6), 411-432.

Kuratko, D. F. (2005). The emergence of entrepreneurship education: Development, trends, and challenges. Entrepreneurship Theory and Practice, 29(5), 577-597.

Kuratko, D. F. (2007). Entrepreneurial leadership in the 21st century: Guest editor's perspective. Journal of Leadership E Organizational Studies, 13(4), 1-11.

Ladzani, W. M., ve Van Vuuren, J. J. (2002). Entrepreneurship training for emerging SMEs in South Africa. Journal of small business management, 40(2), 154161.

Larson, A. (1991). Partner networks: Leveraging external ties to improve entrepreneurial performance. Journal of business venturing, 6(3), 173-188.

Lee, J. (1996). The motivation of women entrepreneurs in Singapore. Women in Management Review, 11(2), 18-29.

Liñán, F., Rodríguez-Cohard, J. C., ve Rueda-Cantuche, J. M. (2011). Factors affecting entrepreneurial intention levels: a role for education. International entrepreneurship and management Journal, 7(2), 195-218.

Lüthje, C., ve Franke, N. (2003). The 'making' of an entrepreneur: testing a model of entrepreneurial intent among engineering students at MIT. REd Management, 33(2), 135-147.

Mazzarol, T., Volery, T., Doss, N., ve Thein, V. (1999). Factors influencing small business start-ups: a comparison with previous research. International Journal of Entrepreneurial Behavior \& Research, 5(2), 48-63. 
McClelland, D. C. (1962). Business drive and national achievement. Harvard Business Review, 40(4), 99-112.

McClelland, D. C. (1965). N achievement and entrepreneurship: A longitudinal study. Journal of personality and social psychology, 1(4), 389.

McClelland, D. C. (1987). Human motivation: CUP Archive.

McGee, J. E., ve Peterson, M. (2019). The long-term impact of entrepreneurial selfefficacy and entrepreneurial orientation on venture performance. Journal of small business management, 57(3), 720-737.

McGee, J. E., Peterson, M., Mueller, S. L., ve Sequeira, J. M. (2009). Entrepreneurial self-efficacy: refining the measure. Entrepreneurship Theory and Practice, 33(4), 965-988.

McGrath, R. G., Mac Grath, R. G., ve MacMillan, I. C. (2000). The entrepreneurial mindset: Strategies for continuously creating opportunity in an age of uncertainty (Vol. 284): Harvard Business Press.

McMullan, W., ve Gillin, L. (2001). Entrepreneurship education in the nineties: Revisited. Entrepreneurship education: A global view, 57-77.

Minniti, M., ve Bygrave, W. (1999). The microfoundations of entrepreneurship. Entrepreneurship Theory and Practice, 23(4), 41-52.

Mitchell, R. K., Busenitz, L., Lant, T., McDougall, P. P., Morse, E. A., ve Smith, J. B. (2002). Toward a theory of entrepreneurial cognition: Rethinking the people side of entrepreneurship research. Entrepreneurship Theory and Practice, 27(2), 93-104.

Mitra, J. (2008). Towards an analytical framework for policy development. In J. Potter (Ed.), Entrepreneurship and higher education. Paris: OECD-Local Economic and Employment Development (LEED).

Mueller, S. L., ve Thomas, A. S. (2001). Culture and entrepreneurial potential: A nine country study of locus of control and innovativeness. Journal of business venturing, 16(1), 51-75.

Muzyka, D., De Koning, A., ve Churchill, N. (1995). On transformation and adaptation: Building the entrepreneurial corporation. European Management Journal, 13(4), 346-362.

Namey, E., Guest, G., McKenna, K., ve Chen, M. (2016). Evaluating bang for the buck: a cost-effectiveness comparison between individual interviews and focus groups based on thematic saturation levels. American Journal of Evaluation, 37(3), 425-440. 
Neck, H. M., Meyer, G. D., Cohen, B., ve Corbett, A. C. (2004). An entrepreneurial system view of new venture creation. Journal of small business management, 42(2), 190-208.

Neumeyer, X., Santos, S. C., Caetano, A., ve Kalbfleisch, P. (2019). Entrepreneurship ecosystems and women entrepreneurs: A social capital and network approach. Small Business Economics, 53(2), 475-489.

Nieman, G. (2006). Business management: A value chain approach: Van Schaik Publishers.

Nykänen, M., Salmela-Aro, K., Tolvanen, A., ve Vuori, J. (2019). Safety self-efficacy and internal locus of control as mediators of safety motivation-Randomized controlled trial (RCT) study. Safety science, 117, 330-338.

O'Connor, A. (2013). A conceptual framework for entrepreneurship education policy: Meeting government and economic purposes. Journal of business venturing, 28(4), 546-563.

Oosterbeek, H., Van Praag, M., ve Ijsselstein, A. (2010). The impact of entrepreneurship education on entrepreneurship skills and motivation. European economic review, 54(3), 442-454.

Orhan, K. (2017). Girişimci kaderini yener mi: girişimci eğilime kaderciliğin etkisi. Uluslararası Yönetim İktisat ve İşletme Dergisi, 13(5), 143-159.

Perry, C., Macarthur, R., Meredith, G., ve Cunnington, B. (1986). Need for achievement and locus of control of Australian small business ownermanagers and super-entrepreneurs. International Small Business Journal, $4(4), 55-64$.

Peterman, N. E., ve Kennedy, J. (2003). Enterprise education: Influencing students' perceptions of entrepreneurship. Entrepreneurship Theory and Practice, 28(2), 129-144.

Peters, M. P., ve Brush, C. G. (1996). Market information scanning activities and growth in new ventures: A comparison of service and manufacturing businesses. Journal of Business Research, 36(1), 81-89.

Putnam, R. D., Leonardi, R., ve Nanetti, R. Y. (1994). Making democracy work: Civic traditions in modern Italy: Princeton university press.

Rauch, A., ve Frese, M. (2007). Let's put the person back into entrepreneurship research: A meta-analysis on the relationship between business owners' personality traits, business creation, and success. European Journal of work and organizational psychology, 16(4), 353-385.

Robinson, P., ve Haynes, M. (1991). Entrepreneurship education in America's major universities. Entrepreneurship Theory and Practice, 15(3), 41-52. 
Rotter, J. B. (1966). Generalized expectancies for internal versus external control of reinforcement. Psychological monographs: General and applied, 80(1), 1.

Schmitt-Rodermund, E. (2004). Pathways to successful entrepreneurship: Parenting, personality, early entrepreneurial competence, and interests. Journal of vocational behavior, 65(3), 498-518.

Sesen, H. (2013). Personality or environment? A comprehensive study on the entrepreneurial intentions of university students. Education+ training, 55(7), 624-640.

Shane, S. A. (2003). A general theory of entrepreneurship: The individual-opportunity nexus: Edward Elgar Publishing.

Shenton, A. K. (2004). Strategies for ensuring trustworthiness in qualitative research projects. Education for information, 22(2), 63-75.

Steel, W. (1994). Changing the institutional and policy environment for small enterprise development in Africa. Small Enterprise Development, 5(2), 4-9.

Strauss, A., ve Corbin, J. (1998). Basics of qualitative research techniques: Sage publications Thousand Oaks, CA.

Taormina, R. J., ve Kin-Mei Lao, S. (2007). Measuring Chinese entrepreneurial motivation: Personality and environmental influences. International Journal of Entrepreneurial Behavior E Research, 13(4), 200-221.

Teece, D. J. (1993). Profiting from technological innovation: Implications for integration, collaboration, licensing and public policy. Research Policy, 22(2), 112-113.

Thomas, K. W., ve Velthouse, B. A. (1990). Cognitive elements of empowerment: An "interpretive" model of intrinsic task motivation. Academy of Management review, 15(4), 666-681.

Thompson, J. L. (1999). The world of the entrepreneur-a new perspective. Journal of workplace learning, 11(6), 209-224.

West, W. (2001). Beyond grounded theory: The use of a heuristic approach to qualitative research. Counselling and Psychotherapy Research, 1(2), 126-131.

Wijbenga, F. H., ve van Witteloostuijn, A. (2007). Entrepreneurial locus of control and competitive strategies-The moderating effect of environmental dynamism. Journal of Economic Psychology, 28(5), 566-589.

Wilson, F., Kickul, J., ve Marlino, D. (2007). Gender, entrepreneurial self-efficacy, and entrepreneurial career intentions: Implications for entrepreneurship education. Entrepreneurship Theory and Practice, 31(3), 387-406. 
Wu, S., Matthews, ve Dagher, G. K. (2007). Need for achievement, business goals, and entrepreneurial persistence. Management Research News, 30(12), 928941.

Yıldırım, A., ve Şimşek, H. (2005). Sosyal bilimlerde nitel araştırma yöntemleri. Ankara: Seçkin Yayıncılık.

Yu Cheng, M., Sei Chan, W., ve Mahmood, A. (2009). The effectiveness of entrepreneurship education in Malaysia. Education+ training, 51(7), 555-566.

Zhao, H., Seibert, S. E., ve Hills, G. E. (2005). The mediating role of self-efficacy in the development of entrepreneurial intentions. Journal of applied psychology, 90(6), 1265.

Zigarmi, D., Galloway, F. J., ve Roberts, T. P. (2018). Work locus of control, motivational regulation, employee work passion, and work intentions: An empirical investigation of an appraisal model. Journal of Happiness Studies, 19(1), 231-256.

\section{Kaynakça Bilgisi / Citation Information}

Çiçek, B. ve Karakaş, Y. E. (2020). Girişimcilerin gözünden girişimciliği etkileyen içsel ve dişsal faktörler. OPUS-Uluslararası Toplum Araştırmaları Dergisi, 15(23), 1849-1884. DOI: 10.26466/opus.631493 